\title{
Spatial characteristics between biodiversity and ecosystem services in a human-dominated watershed
}

\author{
Yang Bai ${ }^{a}$, Changwei Zhuang ${ }^{b}$, Zhiyun Ouyang ${ }^{a, *}$, Hua Zheng ${ }^{a}$, Bo Jiang ${ }^{a}$

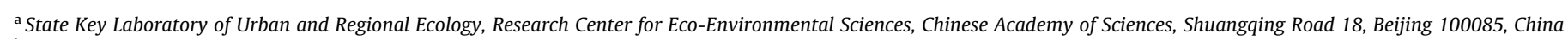 \\ ${ }^{\mathrm{b}}$ Nanjing Institute of Environmental Sciences Ministry of Environmental Protection, Nanjing 210042, China
}

\section{A R T I C L E I N F O}

\section{Article history:}

Received 17 December 2010

Received in revised form 12 January 2011

Accepted 12 January 2011

Available online 26 February 2011

\section{Keywords:}

Biodiversity

Ecosystem service

Hotspot

Congruence

\begin{abstract}
A B S T R A C T
Biodiversity and ecosystem services are intrinsically linked. Since human activities have both intensive and extensive impacts on the environment, it is critical to understand spatial relationships between conservation priorities for biodiversity and ecosystem services. The manner in which various aspects of biodiversity relate to ecosystem services and the spatial congruence between biodiversity and these services, is, however, unclear. In the present study in the Baiyangdian watershed, China, we investigated spatial characteristics of biodiversity and ecosystem services using correlation, overlap, and principal component, analyses. The spatial correlations between biodiversity and ecosystem services were found to be high. Biodiversity was positively correlated with soil retention, water yield and carbon sequestration and negatively correlated with N/P retention and pollination. Pairwise overlap was found to be the highest between $\mathrm{N}$ and $\mathrm{P}$ retention, biodiversity and carbon sequestration, and biodiversity and water yield. Other couples indicated moderate or small overlap. Principal component analysis indicated that biodiversity and six ecosystem services could be divided into two groups, which could be managed and conserved separately. It can be concluded that biodiversity priorities co-occur with water yield, soil retention and carbon sequestration, and do not co-occur with $\mathrm{N} / \mathrm{P}$ retention and pollination. Conservation of a biodiversity hotspot was associated with maintaining $45.02 \%$ of a carbon sequestration hotspot, $42.05 \%$ of a water yield hotspot, and $23.29 \%$ of a soil retention hotspot, indicating that conserving biodiversity will also result in the protection of these services. The bundling of biodiversity and ecosystem services is thus both possible and practical. Our findings provide valuable information on congruence and divergence among conservation hotspots and the protection of ecosystem services. They also indicate that a systematic and comprehensive approach that can have wide-ranging policy implications in terms of optimizing conservation strategies for multiple ecosystem services.
\end{abstract}

(c) 2011 Elsevier B.V. All rights reserved.

\section{Introduction}

Biodiversity and ecosystem services - i.e. the benefits that humans derive from ecosystems - are intrinsically linked: the former underpins most ecosystem services and the maintenance of ecosystem services is often used to justify biodiversity conservation actions, because of the importance of such services in sustaining human livelihoods (Bookbinder et al., 1998; MA, 2005; Naughton-Treves et al., 2005; Egoh et al., 2009). Nevertheless, both biodiversity and ecosystem services are increasingly threatened by human activities (MA, 2005). The hope among conservation biologists and policy-makers alike is that existing and future conservation strategies can deliver on both biodiversity, and ecosystem services (Janzen, 1998; Balvanera et al., 2001; Daily and

\footnotetext{
* Corresponding author.

E-mail address: zyouyang@rcees.ac.cn (Z. Ouyang).
}

Matson, 2008; Goldman et al., 2008; Eigenbrod et al., 2009; de Groot et al., 2010). To achieve this, it becomes necessary to explore the links between biodiversity and ecosystem services (Burkhard et al., 2010).

The relationship between biodiversity and ecosystem services has not been a central concern of ecologists and has not, therefore, been of direct relevance to public policy. Recent studies have identified various important relationships: increases in biodiversity positively affecting productivity but decreasing stability (Pfisterer and Schmid, 2002); and the observation that conservation of biodiversity also results in the provision of additional ecosystem services (e.g. Ricketts et al., 2004; Russ et al., 2004). An IUCN report on post-2010 targets (IUCN, 2009) suggested that new targets could focus on human benefits of biodiversity arising through ecosystem services, which reflect the view that protecting ecosystem services also helps to protect biodiversity. Contrary to these initiatives, Egoh et al. (2009) concluded that the match between biodiversity and ecosystem services is not strong. Naidoo 
et al. (2006) argues further that by ignoring the cost side of conservation planning, ecologists and conservation biologists are missing great opportunities to more efficiently achieve conservation objectives in a world of limited conservation resources. The debate continues.

A more comprehensive understanding of the relationships between biodiversity and ecosystem services and the effectiveness of biodiversity conservation strategies in providing both biodiversity and ecosystem services is thus currently an important ecological issue (Odling-Smee, 2005; Sutherland et al., 2006; Eigenbrod et al., 2009).

The links between biodiversity and ecosystem services are complex (Costanza et al., 2007). Despite extensive discussion on relationships between biodiversity and ecosystem services, details on the ways in which various aspects of biodiversity relate to ecosystem services, and to what extent the conservation of biodiversity will ensure the provision of these services, remain unclear (Egoh et al., 2009; Pert et al., 2010). At present, much conservation effort is geared towards biodiversity per se and our knowledge of conserving ecosystem services is still in its infancy (Balvanera et al., 2001; Egoh et al., 2007).

Some studies have, however, evaluated spatial relationships between biodiversity and ecosystem services. Chan et al. (2006) found a poor relationship between biodiversity and ecosystem services, a generally low correlation between biodiversity and ecosystem services, and a moderate overlap between the two. In another study, Turner et al. (2007) found a generally high overlap between biodiversity priorities and ecosystem services. The ambiguity of these findings suggests that there is a need to extend the investigation into new regions that have not been extensively researched (Egoh et al., 2009).

In an increasing number of regions, the human population is so dense that extensive wilderness areas are entirely lacking. Anthropogenic drivers and their impacts on the relationships between biodiversity and ecosystem services of human-dominated landscapes are thus not well understood. The need to protect biodiversity and ecosystem services within human-dominated landscapes has been recognized by practitioners (Eigenbrod et al., 2009). Given the limited time, available resources, and looming imminent threats, to both biodiversity and to ecosystem services, we emphasize the need to prioritize this process by including human-related factors. In this study we assess the spatial congruence between biodiversity and ecosystem services in the Baiyangdian watershed, China, which is a human-dominated landscape. Specifically, we assess the opportunities for bundling biodiversity conservation with ecosystem services at the watershed scale and identify areas where protection of multiple benefits would be the most efficient. The broad aim of our paper is to present a systematic methodology for protecting biodiversity and ecosystem services in the world's watersheds.

We do this by asking the following questions:

How much of each service is being generated by each land parcel?

To what extent does biodiversity correlate with, or overlap with, other ecosystem services?

\section{Study area and methods}

\subsection{Study area}

The Baiyangdian watershed (Fig. 1) is located in the middle of the north China plain and covers an area of $31,200 \mathrm{~km}^{2}$. It has a complicated topography with higher lands in the west and lower lands in the east. Mountain areas mainly consist of forest and grassland, which accounts for $64.1 \%$ of the total area; plains areas

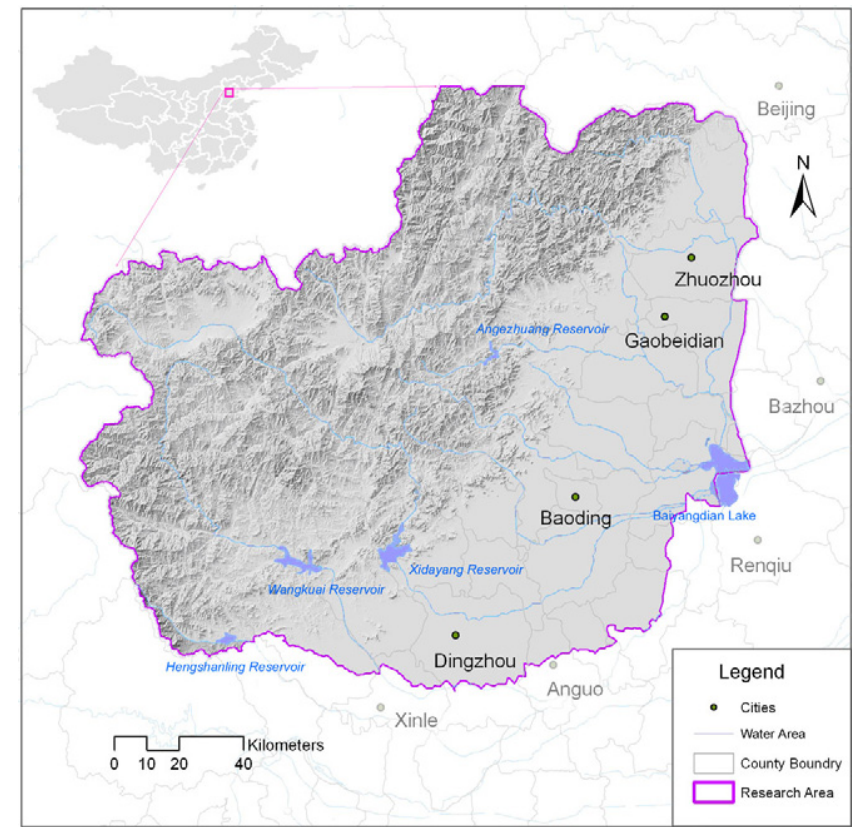

Fig. 1. The Baiyangdian watershed.

are mainly agricultural. Forest, grassland, and agricultural use account for $26.13 \%, 26.74 \%$ and $36.57 \%$ of the total area, respectively. The watershed has a high population density, with more than 448 people $\mathrm{km}^{-2}$ (Note: the average wordwide population density is 45 people $\mathrm{km}^{-2}$ (Central Intelligence Agency, 2008). The area also suffers from extreme water shortages, with an annual average water availability of 3.12 billion $\mathrm{m}^{3}$ and a per capital water availability of $297 \mathrm{~m}^{3}$ ). Due to a combination of natural factors and recent human activities, river runoff has decreased and is burdened with urban domestic sewage, industrial waste and agricultural pesticides and fertilizers, causing serious water pollution. The Baiyangdian watershed therefore faces serious threats.

\subsection{InVEST model and ecosystem services}

In this paper, we apply InVEST (Integrated Valuation of Ecosystem Services and Tradeoffs) to analyze the provision of ecosystem services in the Baiyangdian watershed (Tallis et al., 2010). InVEST was developed as part of the Natural Capital Project (www.naturalcapitalproject.org), a partnership between Stanford University, the Nature Conservancy, and the World Wildlife Fund, working with many other institutions, the aim being an alignment of economic forces with conservation objectives. InVEST combines land use and land management information with information on environmental conditions (e.g., soil and climate information) as inputs into ecological production functions to generate spatially explicit predictions on the supply of ecosystem services. Economic information on the demand for ecosystem services is combined with ecosystem service supply to generate predictions about the use and value of ecosystem services. We illustrate the application of InVEST in mapping and analyzing ecosystem services using biophysical data from the Baiyangdian watershed. For this application, we model biodiversity, carbon sequestration, water quality (nitrogen and phosphorus), soil retention, water yield, and pollination.

\subsubsection{Biodiversity}

We modeled habitat quality as a proxy for biodiversity, ultimately estimating the extent of habitat and vegetation types 
across a landscape and their state of degradation. We assumed that areas with high quality habitat would better support all levels of biodiversity and that decreases in habitat extent and quality over time would result in a decline in biodiversity persistence, resilience, and breadth and depth in the area of decline (Tallis et al., 2010). In our research, habitat quality is a function of four factors: the relative impact of each threat, the relative sensitivity of each habitat type to each threat, the distance between habitats and sources of threats, and the degree to which the land is legally protected (Tallis et al., 2010). Six threats (cropland, rural residential, urban, primary roads, secondary roads and light roads), which represent anthropogenic drivers in human-dominated landscapes, were considered.

\subsubsection{Carbon sequestration}

Carbon storage within ecosystems - in wood, other biomass types, and soil - has the effect of removing $\mathrm{CO}_{2}$ from the atmosphere, where it would contribute to climate change. In addition to simple storage of carbon, many systems also continue to accumulate carbon in plants and soil over time, thereby 'sequestering' additional carbon each year. Our model uses maps of land use and land cover types and data on stocks in four carbon pools (above-ground biomass, below-ground biomass, soil, and dead organic matter) to estimate the amount of carbon sequestered each year within a landscape (Tallis et al., 2010).

\subsubsection{Water quality}

A major impact of land use on water quality is the contribution of nutrients to surface waters. The removal of polluting nutrients and filtration of drinking water are important services provided by functioning ecosystems. Our water quality model evaluates the pollutant removal service provided by a particular landscape. Although there are multiple potentially significant impairments of water quality, in this study we focused on nitrogen $(\mathrm{N})$ and phosphorus (P) (Tallis et al., 2010).

\subsubsection{Soil retention}

Erosion and sedimentation in watersheds can lead to decreased hydropower output, structural damage to reservoirs and other types of water infrastructure, and flooding. We estimate the capacity of a land parcel to retain sediment using data on geomorphology, climate, vegetation and management practices (Tallis et al., 2010).

\subsubsection{Water yield}

The provision of fresh water is an ecosystem service that contributes to the welfare of society. We estimate the annual average quantity and identify the annual water yield contribution from each part of the landscape. This calculation is then used in conjunction with data on mean annual precipitation, annual reference evapotranspiration, and correction factors for vegetation type, soil depth, and plant-available water content (Tallis et al., 2010).

\subsubsection{Pollination}

Crop pollination by bees and other animals is a potentially valuable ecosystem service in many landscapes of mixed agricultural and natural habitats (Allen-Wardell et al., 1998; Free, 1993). Our pollination model focuses on wild bees as a key animal pollinator. It uses estimates of the availability of nest sites and floral resources and bee flight ranges to derive an index of abundance of bee nesting in each cell of a landscape (i.e., pollinator supply). It then uses flight range information to estimate an index of bee abundance visiting each agricultural cell (Tallis et al., 2010).

\subsection{Services hotspots}

'Hotspot' was defined as 'an area that provides large components of a particular service'. We delineated hotspots as the richest $10 \%$ of grid cells for each service, compared to the more traditional 'five percent or less', definition of other studies (van Jaarsveld et al., 1998; Orme et al., 2005; Egoh et al., 2009).

\subsection{Correlation, overlap and principal component analyses}

Services were allocated by 'planning units', defined as the uniform spatial unit of analysis; 15,050 sub-watershed areas were extracted from a DEM and designated as 'planning units'.

Two types of tests - service correlation and hotspot overlap were used in our research to evaluate the spatial concordance of biodiversity and ecosystem services. To estimate service correlation, we calculated correlations (Pearson's $r$ ) between service values across all 15,050 planning units in the watershed. For the hotspot overlap, we calculated the number of cells for each pairwise combination of services that occur in each network and the number of such services that co-occur. We considered two functions of these variables: the ratio of observed to expected numbers of overlapping cells, and the number of overlapping cells as a fraction of the number of cells in the smaller hotspot (Chan et al., 2006).

Baiyangdian watershed contains 33 counties. Principal component analyses were used to analyze spatial differences in services based on these counties.

\section{Results}

\subsection{Services distribution}

Significant values for biodiversity, carbon sequestration, soil retention and water yield hotspot were found in forest, shrub and grasslands, while farmland contained significant values for $\mathrm{N} / \mathrm{P}$ retention and pollination hotspot. No ecosystem service hotspot was found in desert, or urban, areas (Table 1).

Spatial distributions of biodiversity and the six ecosystem services were distinctly different (Fig. 2). The northern and southwestern regions of the watershed were very important for providing multiple services, such as biodiversity, water yield, carbon sequestration and soil retention, while the eastern and

Table 1

Percentage of each ecosystem service hotspot in ecosystems.

\begin{tabular}{|c|c|c|c|c|c|c|c|}
\hline A & Biodiversity & Carbon sequestration & Retention_N & Retention_P & Pollination & Soil retention & Water yield \\
\hline Forest & 43.97 & 66.42 & 0.48 & 0.63 & 0.29 & 39.47 & 48.19 \\
\hline Shrub & 23.27 & 28.40 & 0.31 & 0.44 & 0.29 & 24.64 & 39.74 \\
\hline Grass & 31.37 & 4.59 & 5.36 & 6.00 & 0.55 & 32.64 & 11.50 \\
\hline Wetland & 0.08 & 0.04 & 1.48 & 1.93 & 0.24 & 0.00 & 0.05 \\
\hline Farmland & 1.31 & 0.55 & 92.37 & 91.01 & 98.62 & 3.24 & 0.52 \\
\hline Total & 100 & 100 & 100 & 100 & 100 & 100 & 100 \\
\hline
\end{tabular}

Bold indicates the upper one percentage of each ecosystem service hotspot in each ecosystem. 

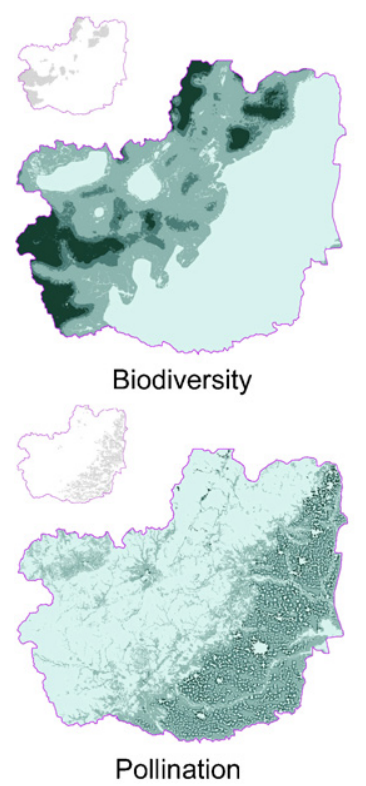

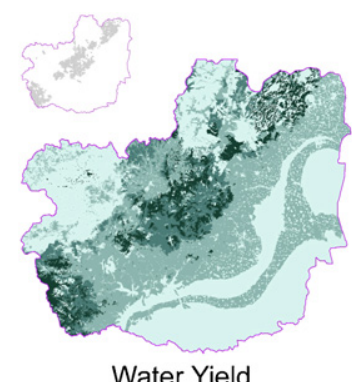

Water Yield

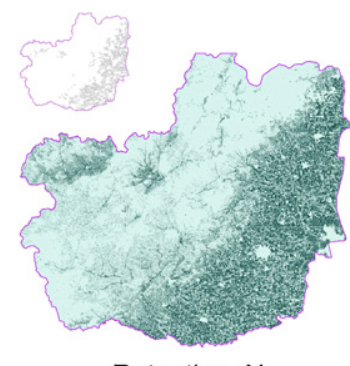

Retention_N

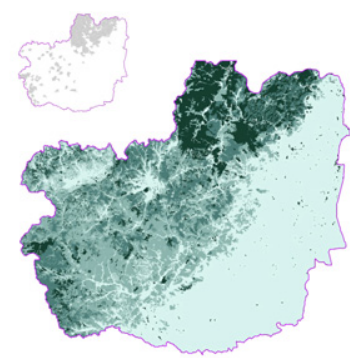

Carbon Sequestration

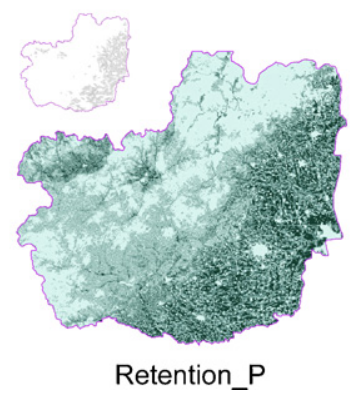

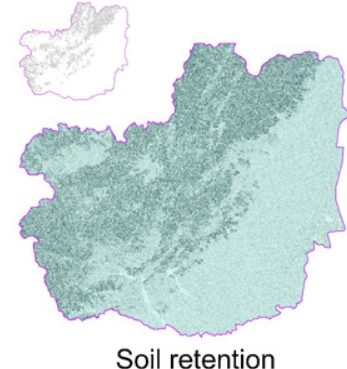

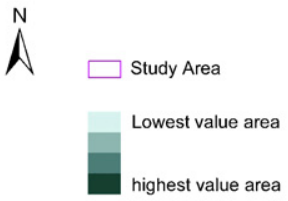

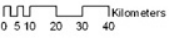

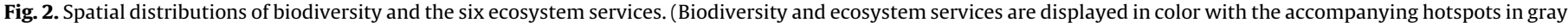
insets. (For interpretation of the references to color in this sentence, the reader is referred to the web version of the article.)

southern sections were important for providing $\mathrm{N} / \mathrm{P}$ retention and pollination.

\subsection{Spatial relationships}

Spatial correlations between ecosystems services were very high (Table 2A): Pearson's $r$ results indicated very significant correlations; biodiversity showed a positive correlation with soil retention, water yield and carbon sequestration and a negative correlation with $\mathrm{N} / \mathrm{P}$ retention and pollination, with the highest positive correlation being with soil retention (0.813) and the highest negative correlation with pollination $(-0.256)$. Generally, the highest correlation was between $\mathrm{N}$ and $\mathrm{P}$ retention (0.93), which was also a positive correlation.
Pair-wise overlaps between the seven hotspots are displayed in Table 2B. In most comparisons, however, the number of shared planning units is less than expected, especially for biodiversity, soil retention and water yield with $\mathrm{N} / \mathrm{P}$ retention and pollination. $\mathrm{N}$ and $P$ retention are, however, the pairs that shared prioritized planning units at higher than expected levels (6.98). Dislike spatial correlation, the highest pair-wise overlap than expected for biodiversity was carbon sequestration (6.02), then water yield (5.62). The same overlaps are shown as percentages of the smaller of the two relevant networks in Table $2 \mathrm{C}$. The results were quite similar. The highest of such overlaps was between retention $\mathrm{N}$ and retention $\mathrm{P}(55.81 \%)$, then between biodiversity and carbon sequestration (45.02\%). Results from proportional overlap analysis (Table 3 ) also showed that retention $\mathrm{N}$ and retention $\mathrm{P}$ had a

Table 2

Pair-wise spatial associations between biodiversity and ecosystem services.

\begin{tabular}{|c|c|c|c|c|c|c|c|}
\hline & Biodiversity & Carbon sequestration & Retention_N & Retention_P & Pollination & Soil retention & Water yield \\
\hline \multicolumn{8}{|l|}{ A } \\
\hline Biodiversity & 1 & & & & & & \\
\hline Carbon sequestration & 0.554 & 1 & & & & & \\
\hline Retention_N & -0.206 & -0.087 & 1 & & & & \\
\hline Retention_P & -0.237 & -0.112 & 0.93 & 1 & & & \\
\hline Pollination & -0.256 & -0.062 & 0.896 & 0.905 & 1 & & \\
\hline Soil retention & 0.813 & 0.668 & -0.195 & -0.226 & -0.237 & 1 & \\
\hline Water yield & 0.535 & 0.288 & 0.501 & 0.506 & 0.541 & 0.494 & 1 \\
\hline \multicolumn{8}{|l|}{ B } \\
\hline Biodiversity & 1.00 & & & & & & \\
\hline Carbon sequestration & 6.02 & 1.00 & & & & & \\
\hline Retention_N & 0.01 & 0.02 & 1.00 & & & & \\
\hline Retention_P & 0.01 & 0.03 & 6.98 & 1.00 & & & \\
\hline Pollination & 0.03 & 0.06 & 3.65 & 3.98 & 1.00 & & \\
\hline Soil retention & 3.11 & 3.04 & 0.01 & 0.02 & 0.01 & 1.00 & \\
\hline Water yield & 5.62 & 0.27 & 0.03 & 0.03 & 0.00 & 2.54 & 1 \\
\hline \multicolumn{8}{|l|}{ C } \\
\hline Biodiversity & 100.00 & & & & & & \\
\hline Carbon sequestration & 45.02 & 100.00 & & & & & \\
\hline Retention_N & 0.10 & 0.17 & 100.00 & & & & \\
\hline Retention_P & 0.07 & 0.23 & 55.81 & 100.00 & & & \\
\hline Pollination & 0.26 & 0.54 & 30.74 & 33.48 & 100.00 & & \\
\hline Soil retention & 37.40 & 36.49 & 0.17 & 0.18 & 0.15 & 100.00 & \\
\hline Water yield & 43.33 & 2.10 & 0.27 & 0.23 & 0.00 & 30.51 & 100.00 \\
\hline
\end{tabular}

Bold in each table indicates the top three associations. 
Table 3

Proportional overlap of hotspot targets achieved between biodiversity hotspot and ecosystem services hotspots.

\begin{tabular}{|c|c|c|c|c|c|c|c|}
\hline & Biodiversity & Carbon sequestration & Retention_N & Retention_P & Pollination & Soil retention & Water yield \\
\hline Biodiversity & 100 & 45.02 & 0.09 & 0.06 & 0.23 & 23.29 & 42.05 \\
\hline Carbon sequestration & 38.60 & 100 & 0.13 & 0.19 & 0.41 & 19.48 & 1.74 \\
\hline Retention_N & 0.10 & 0.17 & 100 & 57.04 & 29.86 & 0.12 & 0.27 \\
\hline Retention_P & 0.07 & 0.23 & 55.81 & 100 & 31.81 & 0.12 & 0.23 \\
\hline Pollination & 0.26 & 0.54 & 30.74 & 33.48 & 100 & 0.11 & 0.00 \\
\hline Soil retention & 37.40 & 36.49 & 0.17 & 0.18 & 0.15 & 100 & 30.51 \\
\hline Water yield & 43.33 & 2.10 & 0.25 & 0.22 & 0.00 & 19.58 & 100 \\
\hline
\end{tabular}

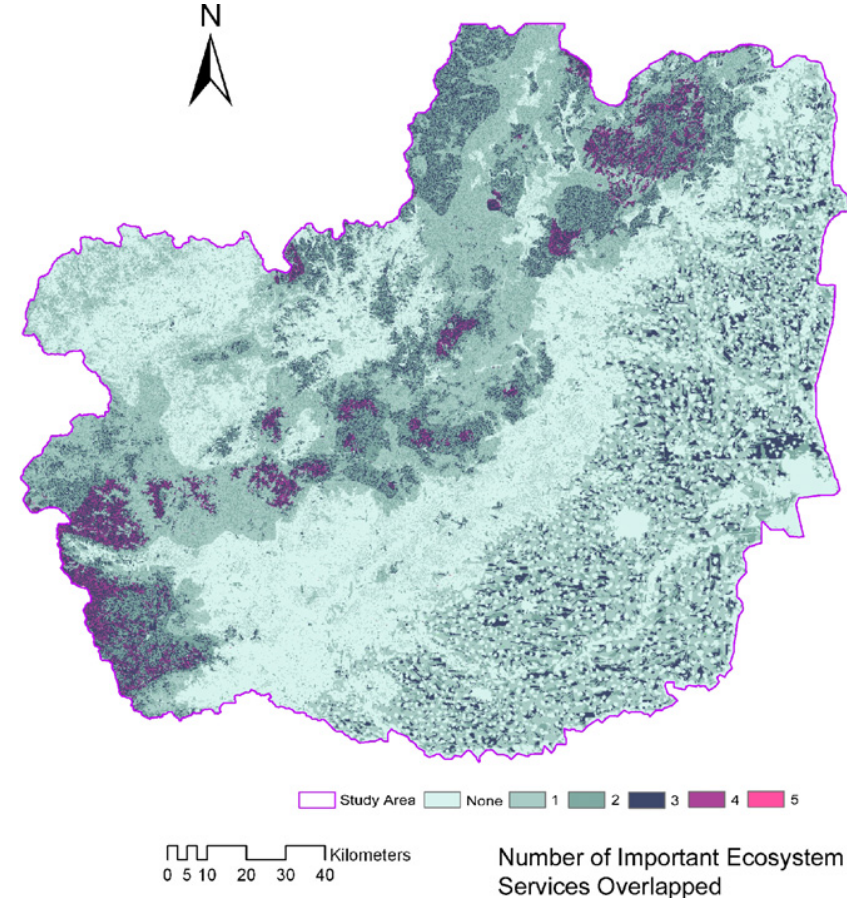

Fig. 3. Ecosystem services hotspots.

relatively high hotspot overlap with each other $(57.05 \%$ and $55.81 \%$, respectively). The lowest hotspot overlap was between water yield and pollination. In the case of the biodiversity hotspot, the highest three hotspot proportions were carbon sequestration (45.02\%), water yield (42.05\%) and soil retention (23.29\%). In the case of the soil retention hotspot, the highest three were biodiversity (37.40\%), carbon sequestration (36.49\%) and water yield (30.51\%). Few services hotspots were achieved in other services hotspots. Fig. 3 illustrates the seven individual services, summed over space, highlighting the distribution of areas selected for different numbers of services. Protecting these high-number areas of multiple benefits would be the most efficient option for conservation management.

\subsection{Grouping ecosystem services}

Principal component analysis (PCA) of biodiversity and six ecosystem services in 33 counties indicated that they can be divided into two groups (Fig. 4A). Group I contained biodiversity, water yield, carbon sequestration and soil retention; and group II contained N/P retention and pollination. While based on ecosystem services in each county, the 33 counties can also be divided into three groups (subregions A-C) from PCA (Fig. 4B). The spatial distribution of the three subregions is shown in Fig. 5: subregion $A$ is mainly in a mountainous area, distributed in the western and northern regions of the Baiyangdian watershed; subregion $B$ is in a plain, distributed in the eastern and southern regions of the Baiyangdian watershed; subregion $C$ is a mountainous-plain zone, distributed in the southern regions of the Baiyangdian watershed.

\section{Discussion}

\subsection{Spatial congruence}

We found a high overlap and correlation between the biodiversity hotspot and three ecosystem services hotspots (water yield, soil retention and carbon sequestration) and little overlap and correlation between three other ecosystem services hotspots $(\mathrm{N} / \mathrm{P}$ retention and pollination and spatial congruence), which supports the findings of Turner et al. (2007). This indicates a general conclusion that biodiversity hotspots often co-occur with certain ecosystem services (such as water yield and carbon
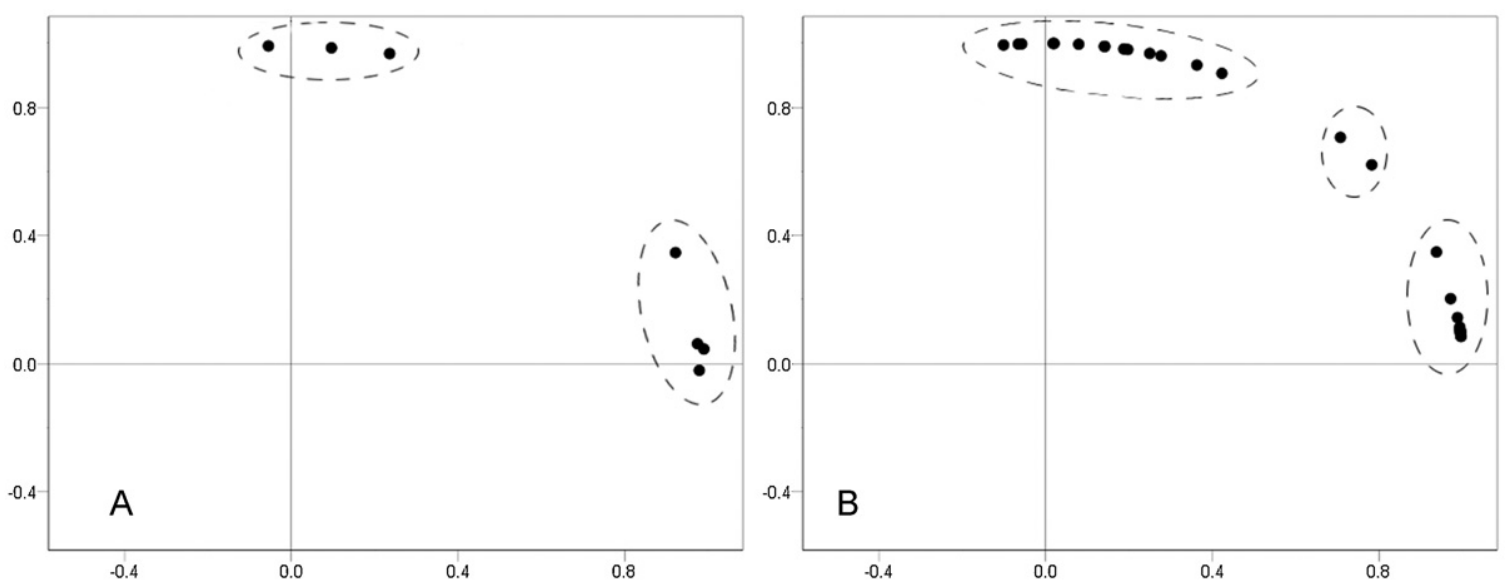

Fig. 4. The results of principal component analyses (PCA) 


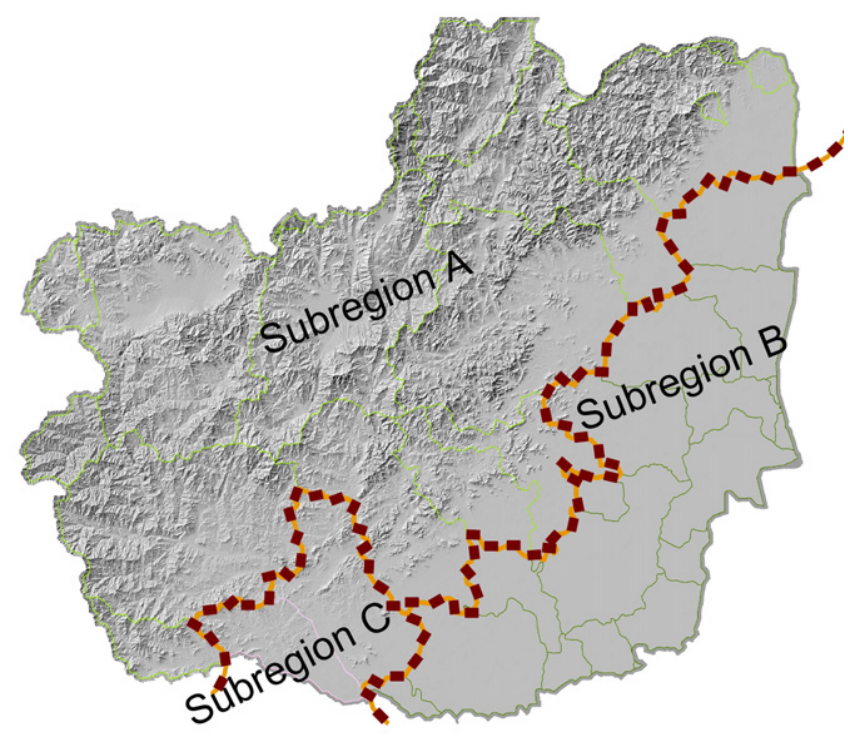

Fig. 5. Spatial distribution of three subregions, from PCA.

sequestration), but do not co-occur with some other ecosystem services (N/P retention and pollination). This suggests that biodiversity conservation strategies can also generate other vital ecosystem services. On the other hand, biodiversity and N/P retention had a highly significant negative correlation, which was not expected since this would indicate that biodiversity priority areas have a low ability for N/P retention. These results may, however, relate to particular areas, so we would rather draw the conclusion that biodiversity does not co-occur with N/P retention.

\subsection{Bundling ecosystem services}

Based on our research, bundling ecosystem services for management was possible. Although the spatial distribution of ecosystem services varied from place to place, biodiversity and ecosystem services can be divided into two groups, based on PCA. Ecosystem services showed a positive relationship within groups, which also showed a high spatial overlap. This contrasts with the observed negative relationship and low spatial overlap between groups. In addition, 33 counties could be divided into three subregions. Results clearly indicated that subregion A mainly provided group I services, and subregion B mainly provided group II services.

Additional proportional overlap analysis indicated that the biodiversity hotspot generally achieved a high proportion of carbon sequestration (45.02\%), water yield (42.05\%) and soil retention (23.29\%). The soil retention hotspot also achieved a high proportion of biodiversity (37.40\%), carbon sequestration (36.49\%) and water yield (30.51\%). Several services often cooccur spatially; conservation was the one service that could also benefit others, especially conservation for biodiversity and soil retention (as indicated in our research). Fig. 3 highlights the spatial distribution of areas selected for different numbers of services. Protecting these high numbers areas of multiple benefits would therefore be the most efficient management option. This indicates that, when formulating conservation strategies, the bundling of ecosystem services can be helpful for optimizing conservation areas.

\subsection{Limitations}

While the information presented here represents an improvement on previous large-scale work on ecosystem services, our study is nevertheless constrained by the limited availability of data. One shortcoming was the use of 'habitat quality' as a surrogate for biodiversity. Due to a lack of information and methodology constraints, several indicators have been previously used as surrogates for biodiversity. For example, Anderson et al. (2009) in their case study for Britain, used only a few species to represent 'biodiversity'. Nelson et al. (2009) who, in their Oregon (USA) case study, found little evidence of trade-offs between biodiversity and ecosystem services, relied on only 24 species as an indication of biodiversity. Species richness (Costanza et al., 2007), species diversity (Thiere et al., 2009), rarity (Chan et al., 2006) were also used as proxies for biodiversity. We suggested that better surrogates were needed, or even that the use of surrogates be abandoned in favor of using direct measures of biodiversity.We only quantified the 'hypotheses' relating to biodiversity and ecosystem services hotspots, rather than measurements relating to these two concepts. Additional measurements of suitable parameters are needed to validate conclusions based on surrogate values and to identify priority areas. Our framework would be the good choice for such an analysis.Our findings - indicating a strong relationship between overlap of biodiversity and ecosystem services - could have been overestimated due to the method that we used for mapping planning units and hotspots: we used a large number of samples ( 15,050 planning units) as well as the top $10 \%$ grid cells identified as hotspot area, in contrast to the more traditional 'five percent or less method' used in other studies (Egoh et al., 2009).In spite of the above-mentioned limitations, our findings have wide-ranging policy implications, illustrating the value of hotspots in humandominated landscapes for representing biodiversity as well as other key ecosystem services. Our results highlighted the difficulty of establishing between biodiversity-N/P retention and pollination in the same area but also demonstrated possible achieving biodiversity and water, and soil and carbon. These results can be used for optimizing conservation strategies for multiple ecosystem services (Chan et al., 2006).

\section{Conclusion}

Previously, the management of most existing conservation areas was mainly concerned with biodiversity (Balvanera et al., 2001; Egoh et al., 2007) and largely ignored the protection of other ecosystem services. According to our research, biodiversity priorities co-occur with water yield, soil retention and carbon sequestration. Conservation of a biodiversity hotspot was associated with maintaining $45.02 \%$ of a carbon sequestration hotspot, $42.05 \%$ of a water yield hotspot, and $23.29 \%$ of a soil retention hotspot, indicating that conserving biodiversity will also result in the protection of these services. Although there are many other potential tradeoffs - such as management efficiency, service beneficiaries and landholders - our systematic and comprehensive approach provides valuable information on the congruence and divergence among biodiversity hotspot and ecosystem services hotspots. Conserving biodiversity can also benefit other ecosystem services. Although a virtual biodiversity conservation hotspot was used in our research, our methods also make use of readily available data and are therefore applicable to other places and situations. For example, our results can be used to examine existing conservation strategies, functions and efficiency, or to assist in conservation hotspot selection, which is vital for practical decision making.

\section{Acknowledgments}

This study was funded by National Key Basic Research Program of China (Grant 2009CB421105, 2006CB403402) and Special 
Foundation from State Key Laboratory of Urban and Regional Ecology. The authors gratefully thank editors and anonymous reviewers for their valuable advice in improving the first manuscript.

\section{References}

Allen-Wardell, G., Bernhardt, P., Bitner, R., Burquez, A., Buchmann, S., Cane, J., Cox, P.A., Dalton, V., Feinsinger, P., Ingram, M., Inouye, D., Jones, C.E., Kennedy, K., Kevan, P., Koopowitz, H., Medellin, R., Medellin-Morales, S., Nabhan, G.P., Pavlik, B., Tepedino, V., Torchio, P., Walker, S., 1998. The potential consequences of pollinator declines on the conservation of biodiversity and stability of food crop yields. Conservation Biology 12, 8-17.

Anderson, B.A., Armsworth, P.R., Eigenbrod, F., Thomas, C.D., Gillings, S., Heinemeyer, A., Roy, D.B., Gaston, K.J., 2009. Spatial covariance between biodiversity and other ecosystem service priorities. Journal of Applied Ecology 46, 888-896.

Balvanera, P., Daily, G.C., Ehrlich, P.R., Ricketts, T.H., Bailey, S.A., Kark, S., Kremen, C. Pereira, H., 2001. Conserving biodiversity and ecosystem services. Science 291, 2047.

Bookbinder, M.P., Dinerstein, E., Rijal, A., Cauley, H., Rajouria, A., 1998. Ecotourism's support of biological conservation. Conservation Biology 12, 1399-1404.

Burkhard, B., Petrosillo, I., Costanza, R., 2010. Ecosystem services-bridging ecology, economy and social sciences. Ecological Complexity 7, 257-259.

Central Intelligence Agency, 2008. The World Factbook. See https://www.cia.gov/ library/publications/the-world-factbook/geos/xx.html.

Chan, K.M.A., Shaw, M.R., Cameron, D.R., Underwood, E.C., Daily, G.C., 2006. Conservation planning for ecosystem services. PLoS Biology 4, 2138-2152.

Costanza, R., Fisher, B., Mulder, K., Liu, S., Christopher, T., 2007. Biodiversity and ecosystem services: a multi-scale empirical study of the relationship between species richness and net primary production. Ecological Economics 61, 478-491.

Daily, G.C., Matson, P.A., 2008. Ecosystem services: from theory to implementation. Proceedings of the National Academy of Sciences of the United States of America 105, 9455-9456.

de Groot, R.S., Alkemade, R., Braat, L., Hein, L., Willemen, L., 2010. Challenges in integrating the concept of ecosystem services and values in landscape planning management and decision making. Ecological Complexity 7, 260-272.

Egoh, B., Reyers, B., Rouget, M., Bode, M., Richardson, D.M., 2009. Spatial congruence between biodiversity and ecosystem services in South Africa. Biological conservation 142 , 553-562.

Egoh, B., Rouget, M., Reyers, B., Knight, A.T., Cowling, M.R., van Jaarsveld, A.S., Welz, A., 2007. Integrating ecosystem services into conservation assessments: a review. Ecological Economics 63, 714-721.

Eigenbrod, F., Anderson, B.J., Armsworth, P.R., Heinemeyer, A., Jackson, S.F., Parnell, M., Thomas, C.D., Gaston, K.J., 2009. Ecosystem service benefits of contrasting conservation strategies in a human-dominated region. Proceedings of the Royal Society B 276, 2903-2911.

Free, J.B., 1993. Insect Pollination of Crops. Academic Press, London.

Goldman, R.L., Tallis, H., Kareiva, P., Daily, G.C., 2008. Field evidence that ecosystem service projects support biodiversity and diversify options. Proceedings of the National Academy of Sciences of the United States of America 105, 9445-9448.

IUCN, 2009. IUCN: 2010 is almost here - now what? Consultation: options for a new vision for biodiversity, http://cmsdata.iucn.org/downloads/iucn_2010 options_paper_draft.pdf.
Janzen, D.H., 1998. Gardenification of wildland nature and the human footprint. Science 279, 1312-1313.

Millennium Ecosystem Assessment, 2005. Millennium Ecosystem Assessment Synthesis Report. Island Press, Washington, DC http://www.millenniumassessment. org/en/Synthesis.aspx.

Naidoo, R., Balmford, A., Ferraro, P.J., Polasky, S., Ricketts, T.H., Rouget, M., 2006. Integrating economic costs into conservation planning. Trends in Ecology and Evolution 21 (12), 681-687.

Naughton-Treves, L.M., Holland, B., Brandon, K., 2005. The role of protected areas in conserving biodiversity and sustaining local livelihoods. Annual Review of Environment and Resources 30, 219-252.

Nelson, E., Mendoza, G., Regetz, J., Polasky, S., Tallis, H., Cameron, D.R., Chan, K.M.A., Daily, G.C., Goldstein, J., Kareiva, P.M., Lonsdorf, E., Naidoo, R., Ricketts, T.H., Shaw, M.R., 2009. Modeling multiple ecosystem services, biodiversity conservation, commodity production, and tradeoffs at landscape scales. Frontiers in Ecology and the Environment 7, 4-11.

Odling-Smee, L., 2005. Dollars and sense. Nature 437, 614-616.

Orme, C.D.L., Davies, R.G., Burgess, M., Eigenbrod, F., Pickup, N., Olson, V.A., Webster, A.J., Ding, T.S., Rasmussen, P.C., Ridgely, R.S., Stattersfield, A.J., Bennett, P.M., Blackburn, T.M., Gaston, K.J., Owens, I.P.F., 2005. Global hotspots of species richness are not congruent with endemism or threat. Nature 436, 10161019.

Pert, P.L, Butler, J.R.A. Brodie, J.E, Bruce, C. Honzak, M., Kroon, FJ., Metcalfe, D., Mitchell, D., Wong, G., 2010. A catchment-based approach to mapping hydrological ecosystem services using riparian habitat: a case study from the wet Tropics. Australia. Ecological Complexity 7, 378-388.

Pfisterer, A.B., Schmid, B., 2002. Diversity-dependent production can decrease the stability of ecosystem functioning. Nature 416 (6876), 84-86.

Ricketts, T.H., Daily, G.C., Ehrlich, P.R., Michener, C.D., 2004. Economic value of tropical forest to coffee production. Proceedings of the National Academy of Sciences of the United States of America 101, 12579-12582.

Russ, G.R., Alcala, A.C., Maypa, A.P., Calumpong, H.P., White, A.T., 2004. Marine reserves benefit local fisheries. Ecological Application 14, 597-606.

Sutherland, W.J., Armstrong-Brown, S., Armsworth, P.R., Brereton, T., Brickland, J., Campbell, C.D., Chamberlain, D.E., Cooke, A.I., Dulvy, N.K., Dusic, N.R., Fitton, M., Freckleton, R.P., Godfray, C.J., Grout, N., Harvey, H.J., Hedley, C., Hopkins, J.J., Kift, N.B., Kirby, J., Kunin, W.E., MacDonald, D.W., Marker, B., Naura, M., Neale, R., Oliver, T., Osborn, D., Pullin, A.S., Shardlow, M.E.A., Showler, D.A., Smith, P.L., Smithers, R.J., Solandt, J.C., Spencer, J., Spray, C.J., Thomas, C.D., Thompson, J., Webb, S.E., Yalden, D.W., Watkinson, A.R., 2006. The identification of 100 ecological questions of high policy relevance in the UK. Journal of Applied Ecology 43, 617-627.

Tallis, H.T., Ricketts, T., Nelson, E., Ennaanay, D., Wolny, S., Olwero, N., Vigerstol, K., Pennington, D. Mendoza, G., Aukema, J., Foster, J., Forrest, J., Cameron, D. Lonsdorf, E., Kennedy, C., 2010. InVEST 1.005 Beta User's Guide. The Natural Capital Project. Stanford.

Thiere, G., Milenkovski, S., Lindgren, P.E., Sahlén, G., Berglund, O., Weisner, S.E.B. 2009. Wetland creation in agricultural landscapes: biodiversity benefits on local and regional scales. Biological Conservation 142, 964-973.

Turner, W.R., Brandon, K., Brooks, T.M., Costanza, R., da Fonseca, G.A.B., Portela, R., 2007. Global conservation of biodiversity and ecosystem services. Bioscience 57 (10), 868-873.

van Jaarsveld, A.S., Freitag, S., Chown, S.L., Muller, C., Koch, S., Hull, H., Bellamy, C., Kruger, M., Endrody-Younga, S., Mansell, M.W., Scholtz, C.H., 1998. Biodiversity assessment and conservation strategies. Science 279, 2106-2108. 